Changing Societies \& Personalities, 2018

Vol. 2, No. 2, pp. 161-182

http://dx.doi.org/10.15826/csp.2018.2.2.035

ARTICLE

\title{
Effects of Modernization and Globalization on Values Change in the Arab World
}

\author{
Malek Abduljaber
}

Saginaw Valley State University, Ann Arbor, USA

\begin{abstract}
This paper argues that social transformation processes generate shifts in public opinion among the public. More specifically, increasing rates of modernization and globalization in the Arab world over the past half century have led to a moving away from religion, tradition, and ethnocentrism to embracing more secular, liberal, and egalitarian values. Ordinary citizens in today's Arab world are more tolerant towards non-Muslims, Americans, and other Westerners more than ever before. They support recognizing Israel as a state at a rate previously unprecedented in the region. Arabs are politically, socially, and culturally more liberal than they have been in the twentieth century. Evidence from the World Values Survey and Arab Barometer clearly convey this observable value change in the region. Underlying causes for this change are arguably due to macro, mezzo, and micro-level changes in peoples' lives resulting from increased modernization and globalization compared to earlier periods. This confirms earlier findings from Western Europe and North America which propose that social transformation processes yield predictable changes in values among mass publics.
\end{abstract}

\section{KEYWORDS}

modernization, globalization, public opinion, Arab world, survey research 


\section{Introduction}

There are many questions about the Arab world that have remained unanswered by political science (Campante \& Chor, 2012; Hamarneh, Hollis, \& Shiqāqī, 1997; Lynch, 2013; Ryan \& Schwedler, 2004; Tessler \& Jamal, 2006; Tessler, et al., 2012; Zogby, 2002; Bayat, 2013). Has there been an attitude shift from traditional to post-materialist issues in the Middle East as has been the case in North America or Western Europe? Are Arabs exceptionally more religious compared to other populations around the world? Do Arabs feel the same about Islam, its role in politics and society, and its meaning compared to half a century ago? Has modernization, globalization, urbanization, and westernization altered ordinary citizens' views on religion, economics, politics, and foreign affairs? Most importantly, have Arabs' perceptions of the Arab/Israeli conflict changed over time? This paper endeavors to answer this set of related questions and shed light on citizens' preference changes in an often-forgotten region in the empirical study of comparative politics: the Middle East.

The study of public opinion in the Arab world suffers from several limitations (Robbins \& Tessler, 2012; Braizat, 2005; Tessler, 2011a; Nisbet \& Meyers, 2011; Gause, 2011; Stoll, 2004). First, most analyses and narratives on the region lack empirical, verifiable, evidence (Telhami, 2006; Gause, 2011; Ciftci, 2012). Analysts and experts on the Middle East rely on sheer conjecture and speculation when describing, prescribing, or prognosing Arab world political development (Zogby, 2002; Robbins \& Tessler, 2012). Second, public opinion in the Arab world is often cast as irrelevant by western political scientists, citing the lack of its coherent ideological structure, significance in determining political outcomes, and fluidity (Robins \& Tessler, 2012; Tessler, 2011b; Nisbet \& Meyers, 2011). Despite such charges, political science literature from the developing world has established robust links between political attitudes among citizens and electoral results, regime survival, and longevity (Ryan \& Schwedler, 2004; Tessler, 2011b; Tessler \& Jamal, 2006; Tessler et al., 2012; Robbins \& Tessler, 2012). More recent dimensional analyses of political ideologies in Eastern Europe, China, India, and the Arab world have established that Arab political attitude structures exist and do not deviate significantly from their Western counterparts (Bayat, 2013; Marinov, 2012).

This research presents many contributions to the study of public opinion in the Arab world. The first section provides an extensive listing of existing data sources on the attitudes of Arab citizens on political, social, economic, and cultural matters across different time periods and geographic locales. This resource provides details on the type, breadth, and usefulness of available data on testing potentially interesting questions concerning important outcomes in the region. Second, the paper provides a possible explanation for the observed attitude changes across the region in the past half century. This theoretical clarification relies on the fundamental hypothesis suggesting that social transformation processes such as modernization and globalization lead to changes in the composition of society where new groups rise and other groups lose ground, generating discernible shifts in public opinion. 
Third, the paper provides evidence on the nature and type of attitude changes among citizens in the region by comparing ordinary citizens' preferences in a number of countries including Algeria, Egypt, Jordan, Morocco, and other states where the data in two distinct periods is available.

\section{Public Opinion Research in the Arab World}

Current literature on public opinion trends toward politics has largely focused on industrialized western countries (Warwick, 2002; Kitschelt, 1992; Inglehart \& Welzel, 2005; Bartolini \& Mair, 2001). This may be due to the assumption that public opinion is only relevant in consolidated democracies (Robbins \& Tessler, 2012; Nisbet \& Meyers, 2011). However, a number of studies have shown the link between voters and political actors, and its ameliorating effect on democratic governance in the developing world (Levitsky \& Way, 2002; Lindberg, 2006; Ryan \& Schwedler, 2004). Although dictators and monarchs attempt to manipulate electoral races for their benefit, holding elections opens a channel of communication between candidates and voters (Gause, 2011; Levitsky \& Way, 2002). Political parties and independent candidates run campaigns on a number of issues relevant to the role of government in the economy and international affairs, appealing to their respective constituencies (Malik \& Awadallah, 2013).

The situation in Algeria, Jordan, Lebanon, Morocco, and Yemen is no different from other hybrid regimes (Robbins \& Tessler, 2012; Ryan \& Schwedler, 2002). Such countries have held regular, relatively free, elections where candidates and voters interacted in a competitive race to fill political offices (Bolleyer \& Storm, 2010; Langohr, 2002; Marinov, 2012; Robbins \& Tessler, 2012). This shows that ordinary citizens' political attitudes count in the political process in hybrid regimes (Bolleyer \& Storm, 2010; Ryan \& Schwedler, 2004). This study focuses on the political space in the Arab world, contributing to the larger literature on political space cross-nationally.

One of the most active areas of research in the Arab world concerns the attitudes and behavior of the so called "Arab Street" (Bayat, 2011; Acemoglu, Hassan, \& Tahoun, 2017). This literature has generated empirical studies exploring the most important political factors defining the attitudes and behaviors of Arab citizens (Bayat, 2013; Robbins \& Tessler, 2012; Tessler, 2011). On the one hand, the empirical investigation of the Arab political space is unsystematic (Ciftci, 2012; Harik, 1987). Usually, researchers limit their focus to one dimension or two arbitrarily and report support patterns of different structural groups in the population (Marinov, 2012; Robbins \& Tessler, 2012). The research typically inspects citizens' attitudes toward particular dimensions (usually support for democracy, political Islam, and the Arab/ Israeli conflict) while leaving out possible defining factors such as trust in political institutions and political leadership (Campante \& Chor, 2012; Ciftci, 2012; Malik \& Awadallah, 2013; Tessler, 2011). Despite this continuous effort, certainty of what concerns the Arab Street remains unclear. The empirical work is often limited to case studies and focuses on idiosyncratic relationships concerning particular countries. 
On the other hand, the theoretical work is often too abstract and difficult to verify using available data. Establishing a more robust link between the empirical world and the theoretical one is needed in order to better understand what the Arab Street wants, and how this influences its behavior. Much of the theoretical research has been devoted to finding and explaining the single, most significant, political factor driving the organizational pattern of political attitudes in the Arab world (Bayat, 2013; Dabashi, 2012). This one-dimensional research usually focuses on political Islam or economic policies. It is hardly justifiable and largely dependent on historically rooted explanations. The lack of consensus and systematic investigation on the number, nature, and independence of defining political factors in the Arab world poses the problem of accumulating unchecked arguments such as that of ascribing a onedimensional nature of the political space in the Arab world.

Despite the paucity in public opinion survey research over the past half century, the last decade has recorded a surge in the growing number of cross-national surveys in the Arab world. The numerous projects present new avenues for public opinion research in the Arab world. Prior to introducing such interesting enterprises, this section provides a brief background on survey research in the Arab world. A quick glimpse at the political science literature on the Arab world points to a dearth of public opinion studies prior to this burgeoning of studies. This phenomenon may be due to the long absence of systematic, nationally representative, samples of Arab countries (Tessler \& Jamal, 2006). An ancillary factor is the nature of authoritarian regimes in the region has made it difficult to conduct reliable survey research regarding sensitive political matters. Nevertheless, some American and Arab social scientists have taken the lead in producing public opinion studies on the Arab world (Tessler, 2003). However, such absence of information has limited the potential contribution of the Arab world experience to just the theoretical and empirical development of the field of Comparative Politics (unlike in Eastern Europe and Latin America where it was possible to develop, test, and examine various types of hypotheses linking political attitudes to democratic transitions).

Early scholars of Arab politics noted the absence of public opinion research on the Arab world (Harik, 1987; Hudson, 1995). Unfortunately, such missing information has resulted in the proliferation of myths and stereotypes regarding Arab citizens (Tessler, 2003; Zogby \& Foundation, 2002). A decade ago, a leading figure on public opinion research in the Middle East, remarked that "in the Arab world, there has been very little serious political attitude research until recently, which has made it difficult to challenge stereotypes about the Arab Street and the Arab mind" (Tessler, 2003, p. 23). Three years later, the founders of the Arab Barometer have argued that a number of factors have led to "emerging opportunities for political attitude research in the Arab world" (Tessler \& Jamal, 2006, p. 17).

This changing climate comes from several different factors. First, social scientists, as well as area specialists, are employing more rigorous techniques to questions regarding the Arab world. Second, the relative modernizing and liberalizing policies undertaken by several Arab regimes made it possible to access and acquire reliable data on ordinary Arab citizens. Finally, the attacks of September 11 on the 
U.S. sparked an interest in learning more about the attitudes of Arabs and Muslims across the globe, including the Arab world. This has led to the emergence of a number of cross-national survey projects investigating the attitudes, beliefs, and values of ordinary Arab citizens.

The World Values Survey (WVS) constitutes one of the most extensive survey instruments, investigating citizens' political attitudes toward government, democracy, and policy preferences in more than 50 countries in its sixth wave. The fourth and fifth waves of the survey included six Arab countries: Algeria, Egypt, Iraq, Jordan, Morocco, and Saudi Arabia. The survey questionnaire generally asks Arab respondents questions regarding numerous political factors such as the role of religion in the state. Further, it investigates attitudes toward emerging post-materialist political issues, including the role of women in politics and society, homosexual rights, and environmentalism since the WVS more generally solicits public opinion on issues more relevant to Western politics (Moreno, 1999). To make the instrument better suited for Arab countries, the principal investigators of the WVS consulted with regional experts to add more relevant items in the questionnaires administered in the Arab world (Tessler \& Jamal, 2006).

Prompted by "the profound gap in understanding between the United States and the Arab world that had become so painfully apparent following September 11, 2001", the Arab Thought Foundation in collaboration with Zogby International launched a public opinion survey project in the Arab World (Zogby \& Foundation, 2002). The project covered seven Arab countries: Egypt, Jordan, Kuwait, Lebanon, Morocco, Saudi Arabia, and the United Arab Emirates. The survey instrument contains items investigating Arab citizens' attitudes, values, and beliefs regarding government and international affairs. The survey heavily focuses on Arab attitudes toward American foreign policy, culture, and the west in general (Lynch, 2013).

The Anwar Sadat Center at the University of Maryland directed by Professor Shibley Telhami in collaboration with Zogby International survey research enterprise has conducted annual Arab public opinion surveys since 2003. The project covers six countries in the Arab World and investigates attitudes regarding government international affairs, American foreign policy, identity, and media (Telhami, 2006). He notes that other surveys, including the Arab Barometer, are more comprehensive when covering political attitudes of ordinary Arab men and women on domestic affairs (including the economy, institutional performance, and trust in political institutions). In addition to the annual polls, the WorldPublicOpinion.org project through the Program on International Policy Attitudes has conducted several surveys across the Middle East between 2005-2015 at the University of Maryland. The information collected through such surveys were conducted with close collaboration of the staff working on the annual polls and producing similar information.

Other Arab surveys have been conducted by the Center for Strategic Studies at the University of Jordan, who conducts regular public opinion surveys on the national and regional level Arab attitudes toward the US and the West in addition to general demographic surveys. The Arab Center for Research and Policy Studies, stationed in Doha, Qatar, has launched the Public Opinion Index in the Arab World, attempting 
to investigate Arab citizens' attitudes in the aftermath of the Arab Spring. The Arab Opinion Index investigates ordinary Arab men and womens' attitudes toward a wide range of issues such as general life satisfaction, economic, social, personal and national security, and satisfaction. Moreover, they include questions regarding democracy, confidence on political institutions, and economic accountability. The center published a report documenting its findings for the 2011 wave. Unfortunately, the data is not available for public use and analysis.

The survey chosen for use in this research, the Arab Barometer, was selected because it is one of the most comprehensive survey research projects investigating the values, beliefs, and attitudes of ordinary Arab men and women in a number of countries throughout the Arab world. Initially, the project started with a cross-national and collaborative research effort in six Arab countries: Algeria, Jordan, Lebanon, Morocco, Palestine, and Yemen (Tessler \& Jamal, 2006). Soon, the project expanded, following its partnership with the Arab Reform Initiative, to include five more countries. The objective of the Arab Barometer is to "produce scientifically reliable data on the politically-relevant attitudes of ordinary citizens, to disseminate and apply survey findings in order to contribute to political reform, and to strengthen institutional capacity for public opinion research" (Tessler, 2011, p. 13; Tessler, Jamal, \& Robbins, 2012). The survey instrument was developed in consultation with other regional democracy barometers, collectively known as the global barometer.

The Arab Barometer has conducted four waves in the Arab World. The first took place in 2006-2007 in Algeria, Jordan, Lebanon, Morocco, Palestine, Kuwait, and Yemen. After the expansion the second wave of the Arab Barometer took place in 2010-11 in Algeria, Egypt, Iraq, Jordan, Lebanon, Morocco, Palestine, Saudi Arabia, Sudan, Tunisia, and Yemen. The third wave of the Arab Barometer took place between 2012 and 2014, surveying Algeria, Egypt, Iraq, Jordan, Kuwait, Lebanon, Libya, Morocco, Palestine, Sudan, Tunisia, and Yemen. The Fourth wave of the survey was conducted in seven Arab nations: Algeria, Egypt, Jordan, Lebanon, Morocco, Palestine, Tunisia, and Yemen between 2016 and 2017. In addition to the aforementioned surveys, the Pew Research Center and Gallup have conducted several polls across the Middle East and the Islamic world. Those surveys included several topics, including public opinions on international affairs, Islam and politics, and relations with the United States and the West.

Despite the burgeoning nature of public opinion research in the Middle East over the past two decades, many of the aforementioned surveys are difficult to obtain by analysts of Middle Eastern affairs given the arduous procedures put in place to obtaining the data from the original publishers. Further, all such available surveys on Middle Eastern affairs are cross-sectional, making it difficult on researchers to conduct analysis of value changes over time in the region. More importantly, public opinion research in the form of surveys in the Middle East is seldom available before the 1990s. This complicates the picture for anyone attempting to understand the underlying causes for public opinion change over the past half century in the region. 


\section{Public Opinion Change}

Modernization theorists have suggested that economic development leads to systematic values change in societies (Aratz, 1988). This thesis stems from the realization that increased rates of education across all levels, rising levels of industrialization, urbanization and division of labor, as well as the dismantling of traditional gender roles generates tangible social, political, and cultural changes that lead to shifts in public opinion. This transformation of attitudes is culminated in moving away from absolutist, traditional, and patriarchal norms, ideals, and beliefs to more relative, tolerant, and egalitarian views of the self, society, political order, and culture. While this prescription is said to be probabilistic rather than deterministic, modernization theory still holds that improvements in income, education, institutionalization, technological advancement, empowerment of females, and greater levels of industrialization, urbanization and population densities are associated with predictable political and cultural changes across societies (Marsh, 2014; Bordoloi \& Doss, 2017).

At the core of modernization theory lays its basic principle: the replacement of traditional values with a set of modern values due to significant changes in the economy and society at a given time and place. Lerner (1958), Weiner (1966), Tipps (1973), Arat (1988), Marsh (2014), and Bordoloi and Doss (2017) suggested that the lack of economic development, persistence of traditional cultural traits, existence of traditional institutions have led to the underdevelopment of many developing nations. Such perspectives viewed Western modes of capitalism as an inevitable way of achieving modernity; therefore, developing countries should reject their traditional systems and replace them with modern economic, social and cultural institutions if they desired to modernize. Increased economic, cultural, and military development, as it occurred in Western nations, was observed as the causal processes leading to modernization. This paradigm has undergone great criticism due to its victimization logic. It viewed underdeveloped countries as active agents that reject modern values and institutions, therefore suffering from underdevelopment (Marsh, 2014). Many social scientists have declared modernization as a moot model for cultural change since it neglects the significant influence of external forces such as colonialism, neo-colonialism, globalization, world hegemony and other forms of state international dominance (Weiner, 1966; Lerner, 1958). Many political scientists viewed underdevelopment as an outcome of hegemonic influence exercised by world powers limiting the economic development of the developing world. This rejectionist view of modernization believed that the only way leading to the fulfilment of economic development is the liberation of the developing world economies from the developed world restraints (Bordoloi \& Doss, 2017).

Despite the great criticisms levelled against modernization theory, its central claim that economic development generates predictable cultural, social, and political values changes still enjoys theoretical and empirical popularity across the social and behavioral sciences (Marsh, 2014). Cross-national studies indicate that economic development pushes societal change in a relatively unified prescribed manner. Economic development is associated with increases in industrialization, 
labor specialization, greater educational attainment and rising incomes. Such structural changes lead to predictable cultural shifts, more tolerant views towards out-groups, more favorable views for gender equality, more challenge to religion and authority, greater political activism and more literate citizenry (Aratz, 1988).

More recent understandings of modernization theory propose that the shift from industrialization into post-industrialization marked with the movement of occupations from factories into the service sector has influenced cultural values change (Marsh, 2014). This change from absolutist perceptions (concern for physical and spiritual survival, and emphasizes issues of religion, law, order, and economy) to postmaterialist values (concern for the environment, diversity, gender equality, etc., while emphasizing individual autonomy, relative perceptions, and lifestyles) is associated with the movement from industrialization to post-industrialization (Bordoloi \& Doss, 2017). Modern conceptions of modernization theory suggest that cultural changes due to economic development occur at two junctures. First, the move from agrarian to industrialized economies is associated with cultural shifts emphasizing issues of economic growth, law and order, and religion and state. Second, the replacement of industrial complexes with the service sector moves the emphasis toward a new set of cultural issues: individual expression, autonomy, lifestyles, environment, and gender equality (Aratz, 1988; Marsh, 2014).

The underlying mechanism by which modernization leads individuals to change their cultural values lies in the nature of the relationship between humans and their immediate environments (Tipps, 1973). In pre-industrial societies, individuals grapple with nature directly and have minimal control over natural forces. This leads them into emphasizing the role of the divine, God, and family, since they spend most of their time interacting or thinking about such elements. Once societies become industrialized, humans control of their environments and nature increases with technological advancement and rational choices. The relationship between them, God, nature, and the family dwindles due to an increase in their secular interpretation of their worlds and the relationships governing such interactions (Weiner, 1966). In post-industrial societies, humans have more control over nature and deal less with machinery and production. They spend more time communicating with each other, processing information, and becoming better at making decisions, using technology to improve their lives, and spending more time socializing in the workplace, as well as outside of the workplace. This makes humans value themselves, the quality of their lifestyles, their immediate environments, sustainability of their livelihoods, and the well-being of themselves and their loved ones increasingly. Individuals, therefore, move further away from materialist and spiritual perceptions and into self-driven concerns (Lerner, 1958).

\section{Globalization}

Many social scientists have argued that social transformation processes, such as globalization, lead to predictable shifts in cultural values. While less developed across the behavioral and social science literatures, globalization is said to bring about tangible changes in societies and to lead citizens to abandon, espouse, or 
modify existing or new preferences (Inglehart \& Welzel, 2004). Globalization gives rise to new forms of disparities, competition, and opposition. Citizens around the world perceive such realities in terms of either victories or losses depending on their economic, social, and cultural positions within their own environments. Globalization leads to the political articulation of such new forms of inequalities by formal political institutions such as parties, governments, or non-governmental actors. The evolution of citizens' perceptions is largely informed by the new realities caused by the increase of economic, social, and cultural integration (Hudson, 1995; Inglehart \& Welzel, 2004).

Globalization hurts individuals and groups who are protected by nationalization and protectionist policies (Tipps, 1973; Gause 2011). The decrease of states' controls over segments of their economy, society, and culture poses imminent threats to the social status and security of those enjoying the benefits of the state control. In other words, the economic, social, and cultural viability of such groups are increasingly jeopardized as globalization increases (Gause, 2011). On the contrary, globalization creates opportunities for new individuals and groups whose lives are enriched due to the increase in market integrations, migration, and multiculturalism (Malik \& Awadallah, 2013). To determine whether an individual or group is a winner or loser in globalization, the amount of exit options an individual or group possesses must be assessed. The more options available to an individual or group, the better chances they have of rendering themselves winners in the process. On the one hand, the more options one has the more socially mobile he or she becomes. Converting possessed economic, human, and social capital into resources allows the individual to mitigate the negative externalities brought by globalization and places the demarcation line between the winners and losers in the process (Marsh, 2014).

Globalization has led to structural changes in at least three discernable ways. First, globalization has resulted in an increase in economic deregulation which has led to the erosion of sheltered sectors of the economy. This change has initiated the emergence of a labor force cleavage between those advocating for lowering production costs by the slashing of employee benefits or outsourcing jobs and those who favor stateimposed protectionist economic securities that guarantee higher wages for workers in sheltered industries (Malik \& Awadallah, 2013; Aratz, 1988). Second, globalization has resulted in a significant increase in human migration across countries. While many describe this movement by referencing only migration from the East to the West, recent developments across the world have led to massive waves of internal displacement within regions (such as the Middle East's refugee crises and the movement of large numbers of people within the Eastern hemisphere) (Lerner, 1958; Bayat, 2013; Acemoglu, Hassan, \& Tahoun, 2017). Many individuals feel culturally threatened by the large influx of immigrants into their own communities. This has resulted in a new global cleavage between proponents of multiculturalism and advocates for assimilation (Stoll, 2004; Tipps, 1973; Kitschelt, 1997). Third, globalization leads to the formation of new political alliances, arrangements, and competitions. Many actors emerge as winners or losers depending on the amount of social status, prestige, resources, and leverage gained or lost due to such developments. Individuals are likely to develop, modify, 
and abandon preferences on many issues due to globalization (Harik, 1987; Jackman, 1998; Stoll, 2004; Tessler, 2003).

\section{Data and Methods}

The data sources for this research come from the first and fourth waves of the Arab Barometer, as well as the fourth and sixth waves of the World Values Survey. Notice that data included in the analysis only covers the nations that were surveyed in both waves in order to maximize the comparative scope of the research. The Arab Barometer waves included data on five Arab nations: Algeria, Jordan, Lebanon, Morocco, and Palestine. Both waves were conducted by Arab researchers partnering with University of Michigan and Princeton University researchers in the United States. Note that the interviews were held face-to-face with respondents and in Arabic unless specified otherwise, as was the case of a few Algerian citizens who preferred French. Both waves were based on nationally representative samples prepared by the country's partners in the Arab Barometer project.

According to the methodological notes of the survey, the population of subjects included citizens of 18 years of age and above in all surveyed countries. This includes the entire population living in the surveyed countries, including urban and rural areas. Clearly, this population does not include any inaccessible subjects such as those hospitalized, imprisoned, or on active duty. The sampling design followed by the researchers was a stratified multi-stage cluster sampling technique for each country. Government or state was the most important stratifications so as to ensure geographic representation of populations living across each country. Individuals who conducted the face-to-face interviews undertook rigorous training and were tested before their release to the field in order to ensure higher response rates and reliable answers.

The World Values Surveys started to cover Arab nations in the fourth wave, 1999-2004, by surveying Algeria, Morocco, Jordan, Iraq, Egypt, and Saudi Arabia. The most recently available wave of surveys, the sixth, included data on Algeria, Egypt, Jordan, Morocco, and Iraq. More nations were included in the two surveys; however, since earlier rounds did not include such nations. As discussed previously, data from such included nations is not available for the 1970s or 80 s, thus limiting the availability of a sufficient time difference for detecting significant changes in values. Notice that all items used in the analysis were the same for the two waves in each survey so as to reduce variability in responses and maximize the ability to generate comparable findings.

This study utilizes a variety of numerical and graphical descriptive statistics tools for describing political attitudes in the Arab world. Frequencies, Bar Graphs, Line Charts, measures of central tendency, and variation are utilized to better explore ordinary citizens' political attitudes in the region. Comparisons of similar items, from the first wave of the Arab Barometer to the items from the fourth wave of the survey, are presented to detect any discernable changes. The use of such techniques is informed by the overall exploratory research design objective for this analysis. 


\section{Results}

The Arab world has become more globalized today than ever before. KOF Index of Globalization scores, a general metric of the extent to which nation-states are globalized, have steadily increased in Algeria, Egypt, Jordan, Lebanon, Morocco, and Tunisia over the past half century as indicated in figures 1 to 6 . Between 1970 and 2014, the KOF scores have almost doubled in most Arab countries, indicating more economic, social, and political integration into the world. Arab nationstates have less economic restrictions on the flow of goods, services, and capital today compared to a few decades ago. They have increased their capabilities of collecting and sharing data on economic flows and have established many bodies to encourage, facilitate, and promote economic cooperation both regionally as well as internationally. Cultural and social data collection efforts have also significantly increased and improved, thereby allowing governments and interested stakeholders to better assess the degree of cultural proximity, as well as personal contact, across the region and with the rest of the world. All in all, the Arab world is more globalized than ever.

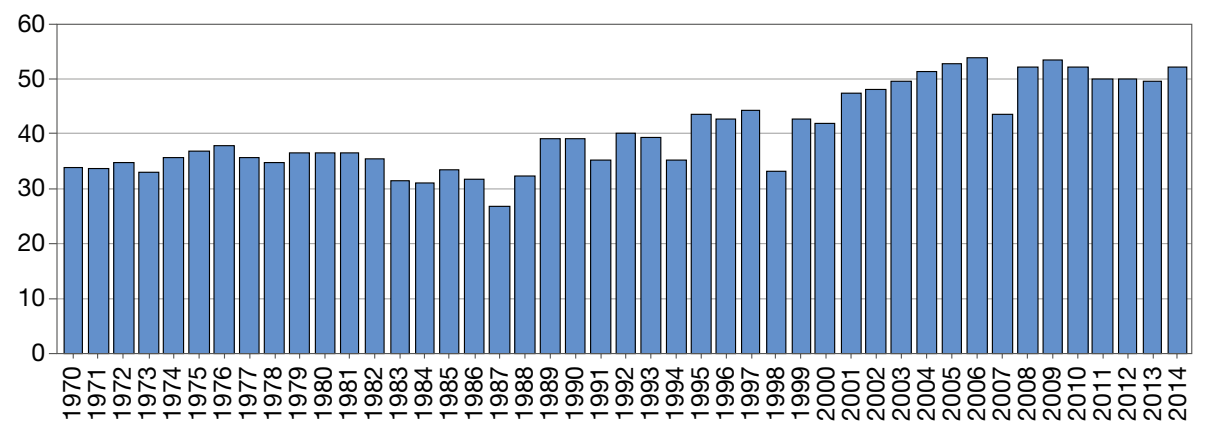

Figure 1. KOF Index of Globalization scores for Algeria

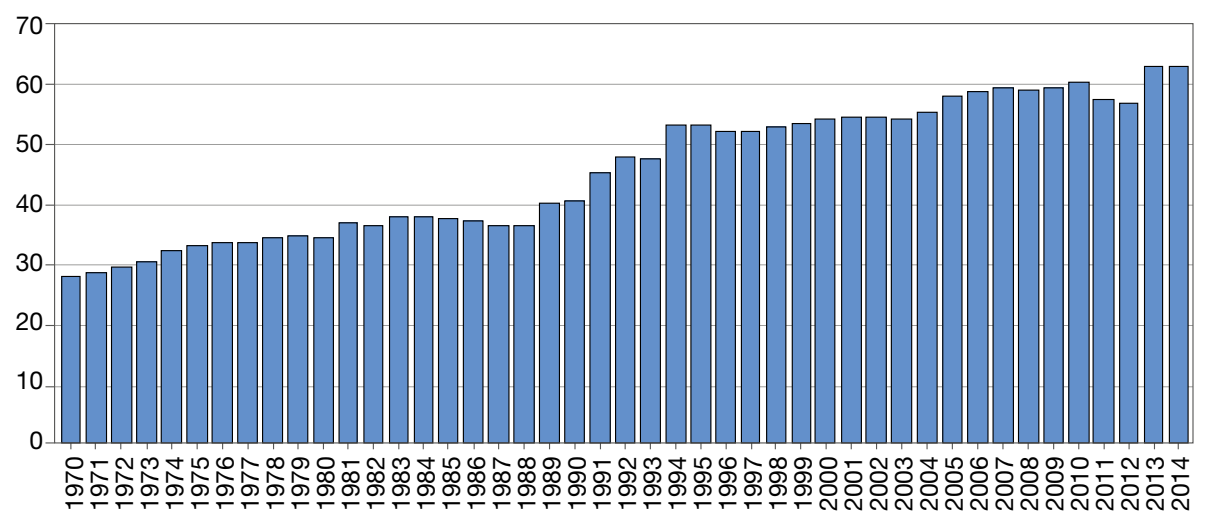

Figure 2. KOF Index of Globalization scores for Egypt 


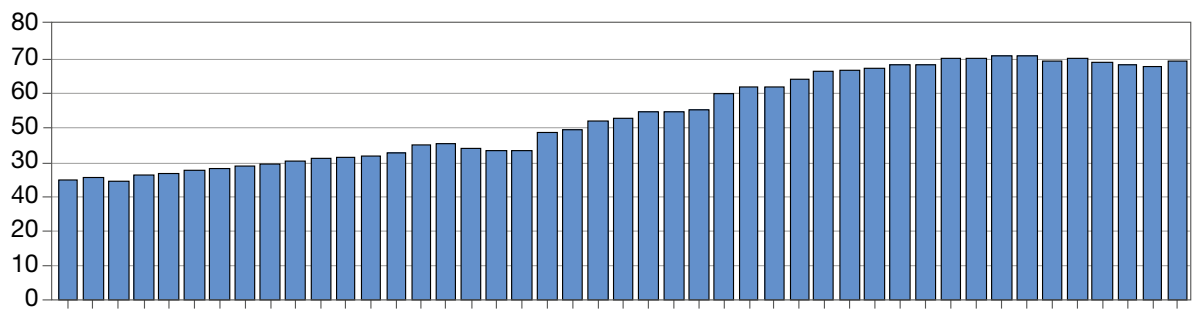

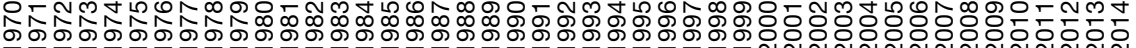

Figure 3. KOF Index of Globalization scores for Jordan

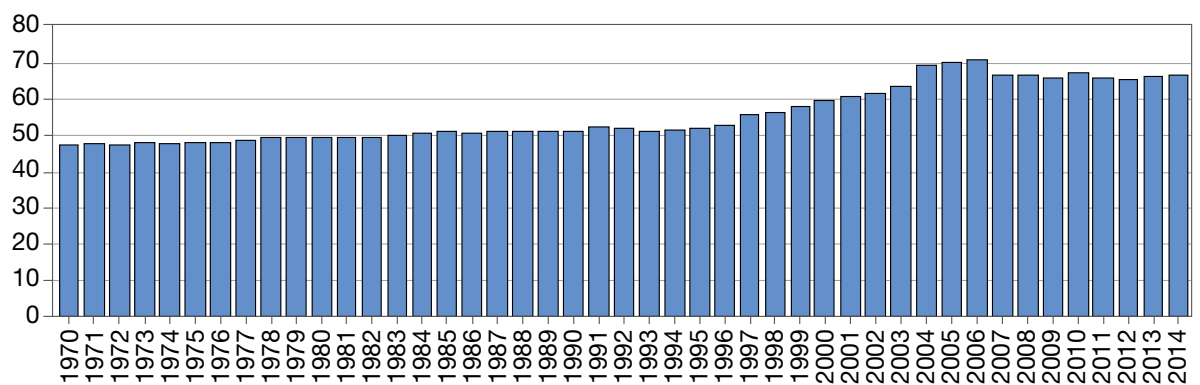

Figure 4. KOF Index of Globalization scores for Lebanon

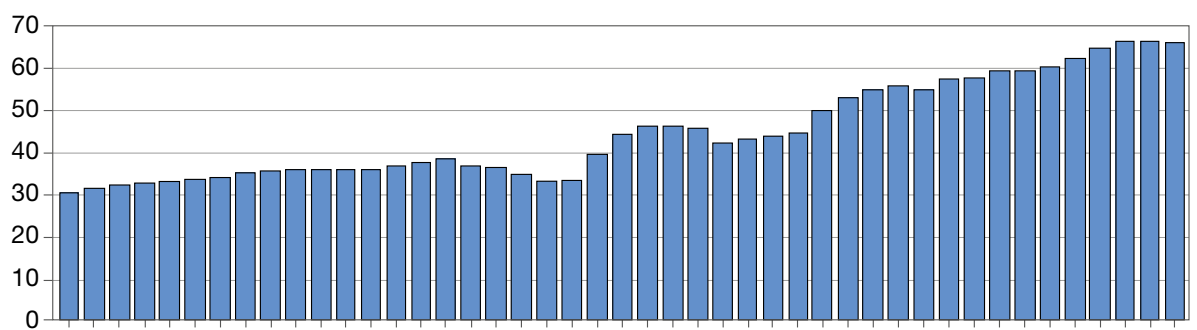

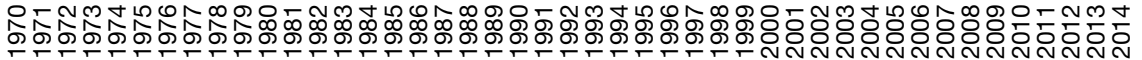

Figure 5. KOF Index of Globalization scores for Morocco

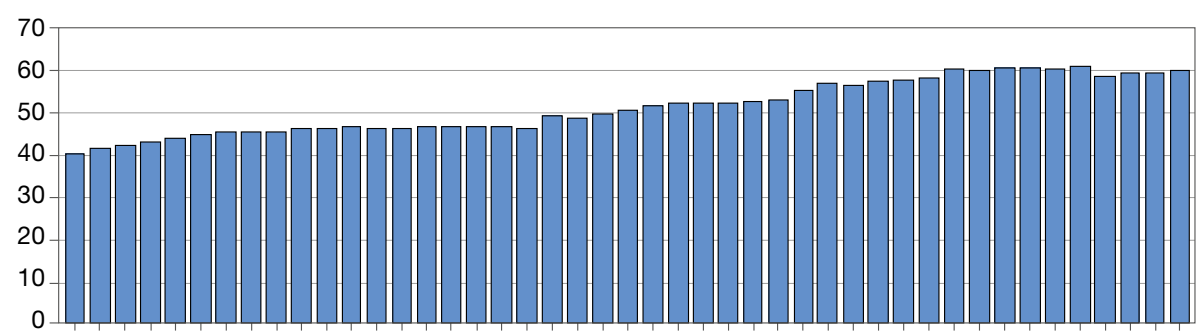

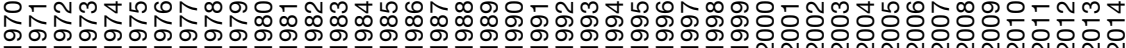

Figure 6. KOF Index of Globalization scores for Tunisia 
The Arab world has also become more modernized than ever before. All Arab countries generate higher gross domestic products (GDPs) than they have previously been capable of in their short histories. While the contribution of agriculture to their economies is dwindling, the service sector has simultaneously been the single most productive sector of economic activity across many countries in the region. Figure 7 shows the GDP in current \$US for a selection of Arab states (Saudi Arabia, The United Arab Emirates, Bahrain, Egypt, Algeria, Tunisia, Morocco, Jordan, Lebanon, Syria, and Iraq). GDP across the region has increased significantly over the past half century. For instance, the GDP of Saudi Arabia arose almost three-fold between 2000 and 2014, rising from about $\$ 189$ to $\$ 755$ Billion. Similarly, Jordan's GDP rose from less than $\$ 10$ Billion in 2000 to about $\$ 30$ Billion in 2015. This increase in GDP is indicative of broader economic growth across the region, where more services, products, and business are being generated in such countries compared to a few decades ago.

Figure 8 represents the percentage of GDP derived from agricultural based value-added activity in the Arab world. Virtually, across all Arab states, the percentage of agriculture-based economic contribution to the total GDP has decreased in the past few decades. This indicates that governments and people across the Arab world are moving away from agriculture to industrial and service oriented economies. Figure 9 indicates the percentage of GDP derived from service-based economic activity in the Arab world. It demonstrates that Lebanon, Jordan, Morocco, and Tunisia rely heavily on the service sector with more than $60 \%$. While it has increased at a slower pace, however, it has been steady in contributing to the oil rich economies of Saudi Arabia, the United Arab Emirates, and other Gulf Cooperation Council member states.

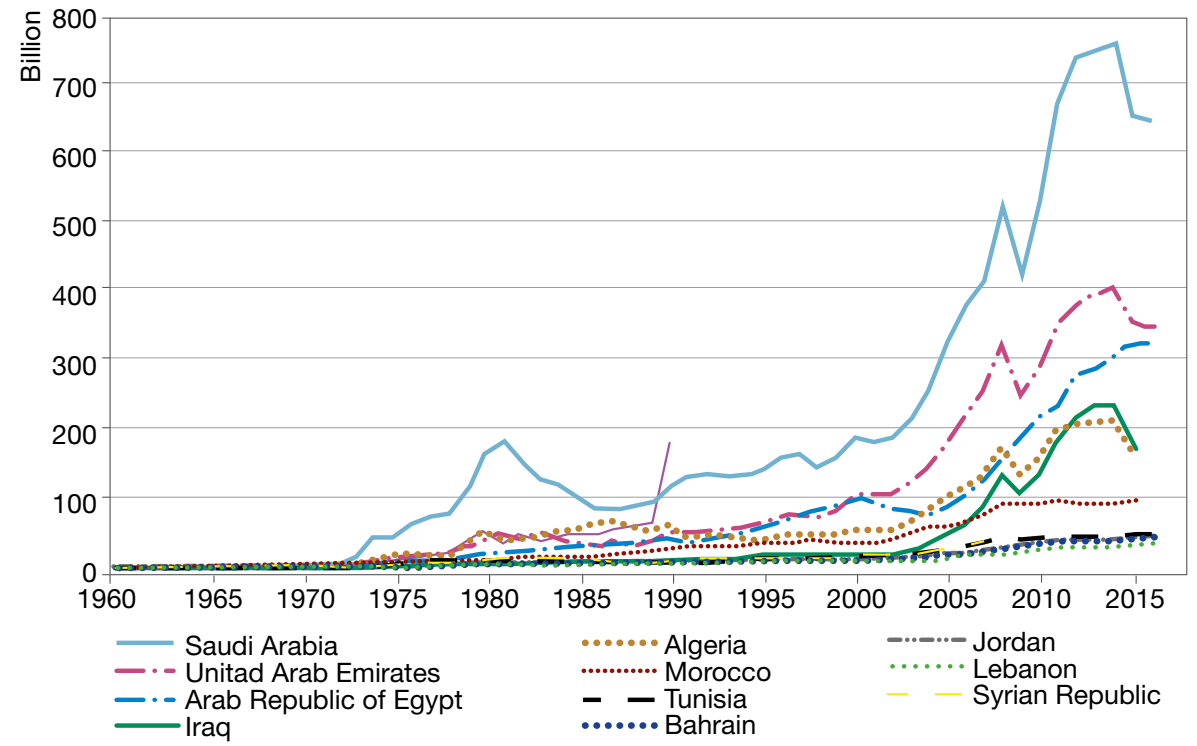

Figure 7. GDP in \$US for Saudi Arabia, the UAE, Bahrain, Egypt, Algeria, Tunisia, Morocco, Jordan, Lebanon, Syria, and Iraq 


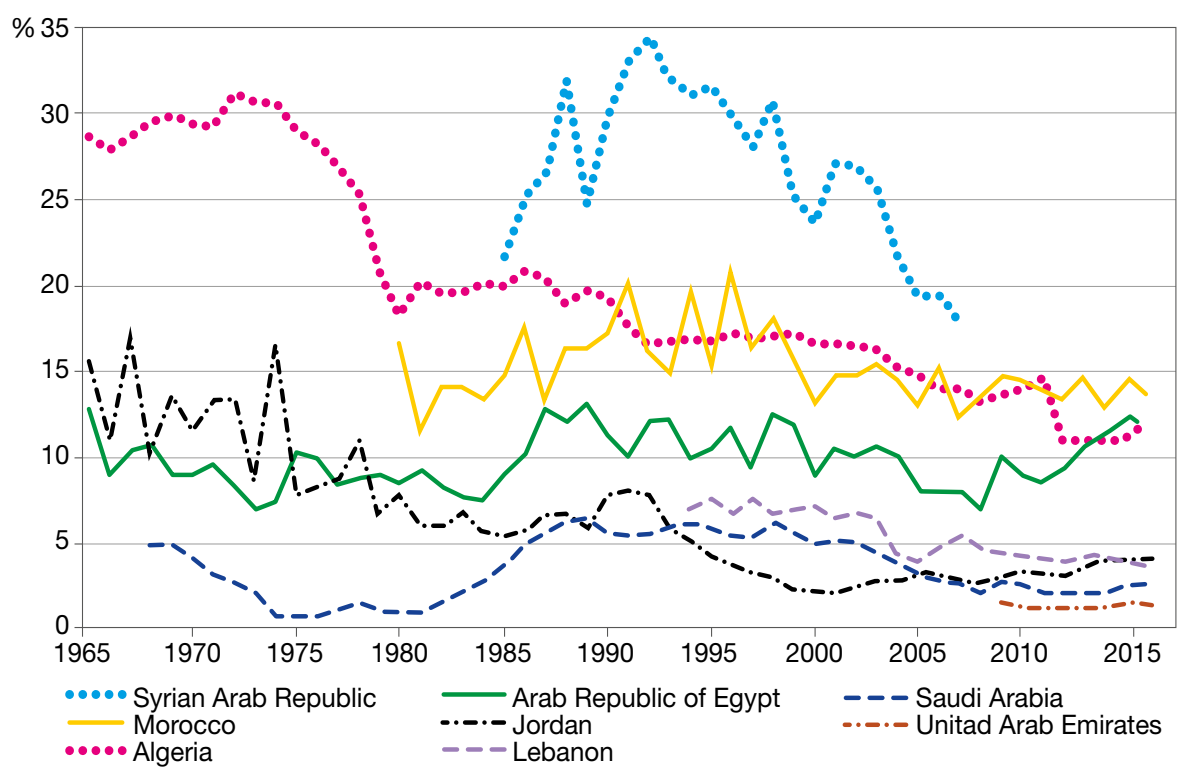

Figure 8. Percentage of GDP from agricultural based value-added activity in the Arab World

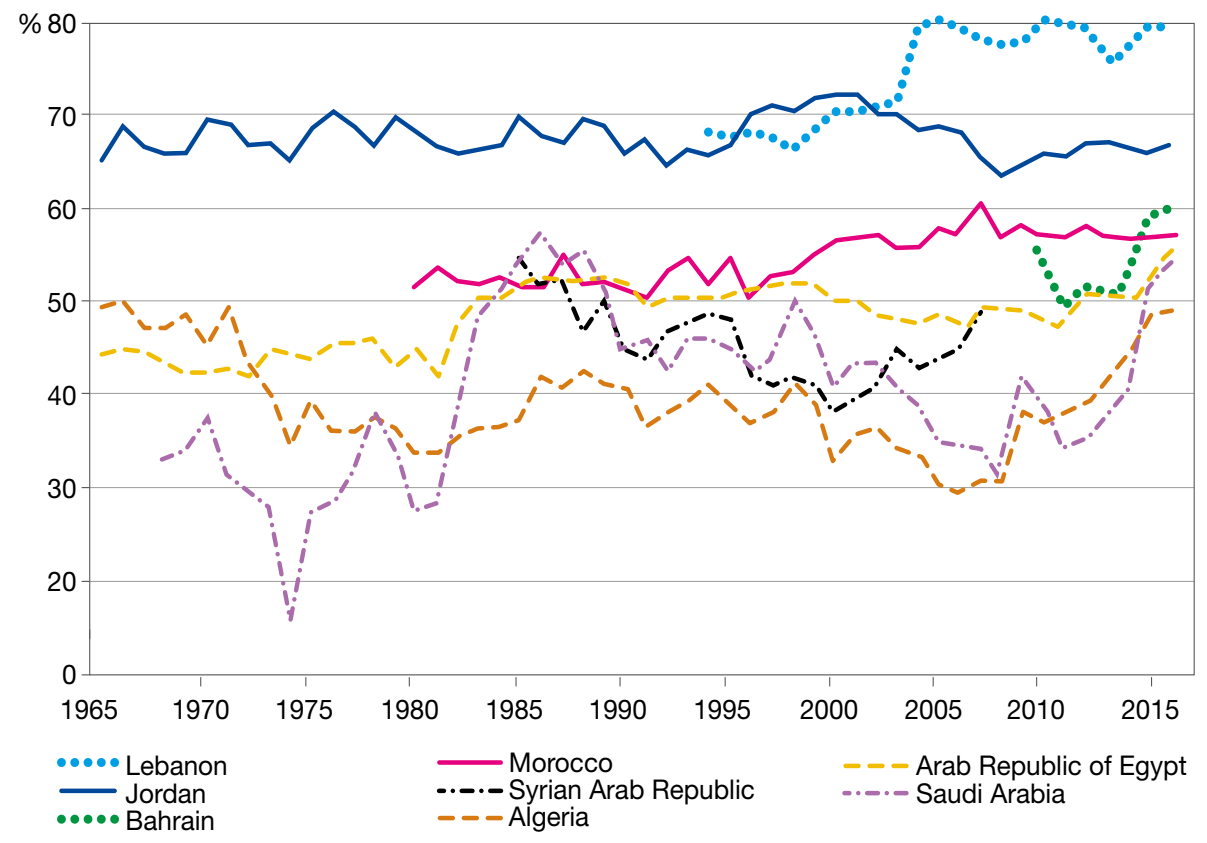

Figure 9. Percentage of GDP

from service-based economic activity in the Arab World 
The Arab world has undergone major strides in fulfilling the promise of gender equality. While realizing the objective of gender equity has not been fully achieved and great barriers to accomplishing this noble normative state of affairs still exists, evidence points to a positive outlook for females today in the Arab world. In all Arab countries virtually all of the Gender Inequality Index scores have decreased over the past half century as indicated by Table 1. Further, female participation in the labor force across the Arab world is increasing at a steady pace. Conservative Gulf Cooperation Council states, such as Saudi Arabia and the United Arab Emirates, are leading the way in the region by putting more females behind desks, in government posts, and decision making pathways throughout various industries. Females are also gaining university degrees at a faster rate than ever before across the region, subsequently becoming more active politically, socially, and culturally. Today, the Arab world has witnessed a qualitative change in gender equity, thus making noticeably positive strides toward gender egalitarianism.

Table 1

Gender Inequality Index Scores for Algeria, Iraq, Egypt, Morocco, Jordan, Saudi Arabia

\begin{tabular}{l|r|r|r}
\hline \multicolumn{1}{c|}{ Country } & \multicolumn{1}{c|}{1995} & 2005 & \multicolumn{2}{c}{2015} \\
\hline Algeria & .680 & .561 & .429 \\
Iraq & .658 & .536 & .525 \\
Egypt & .665 & .581 & - \\
Morocco & .713 & .580 & .494 \\
Saudi Arabia & - & .672 & .257 \\
\hline
\end{tabular}

\section{Values Change in the Arab World}

\section{Religiosity}

Table 2 represents agreement levels of Jordanian, Palestinian, Moroccan, Lebanese, and Algerian samples with the extent to which religious figures influence politics. Results indicate that, across the board, Arab citizens favor less religious interference with politics in the five nations. Noticeable drops in agreement regarding the influence of religious leaders are observed in Jordan, Palestine, Algeria, and Morocco. Lebanon seems to be stable with regard to its citizens' perceptions of religion and politics. Lebanese citizens favor less Islam and Christianity in their political arrangements favoring a more secular form of government.

Table 2

To what Extent do you Agree or Strongly Agree with the Following Statements?

\begin{tabular}{l|r|r|r|r}
\hline \multirow{2}{*}{ Country } & \multicolumn{4}{|c}{ Year } \\
\cline { 2 - 5 } & $\begin{array}{c}\text { Religious People } \\
\text { Hold Public } \\
\text { Office, \% }\end{array}$ & $\begin{array}{c}\text { Men of Religion } \\
\text { Should Influence } \\
\text { Politics, \% }\end{array}$ & $\begin{array}{c}\text { Religious People } \\
\text { Hold Public } \\
\text { Office, \% }\end{array}$ & $\begin{array}{c}\text { Men of Religion } \\
\text { Should Influence } \\
\text { Politics, \% }\end{array}$ \\
\hline Jordan & 44 & 34 & 43 & 31 \\
Palestine & 59 & 45 & 45 & 40 \\
Lebanon & 12 & 13 & 16 & 15 \\
Algeria & 45 & 40 & 40 & 40 \\
Morocco & 66 & 41 & 39 & 23 \\
\hline
\end{tabular}


Figure 10 displays the percentage of ordinary citizens in Lebanon, Morocco, Algeria, Jordan, and Palestine who self-identified with religion or ethnicity (Arab or Muslims for most respondents) in 2006 and 2016. Results indicate a significant decrease in identifying as an Arab or Muslim in the decade separating the two surveys. About $70 \%$ to $80 \%$ of Algerians, Jordanians, and Palestinians identified as Arab or Muslim in 2006, whereas only $30 \%$ to $45 \%$ of the same populations identified themselves with either a religion or ethnicity in 2016. By the same token, the Moroccan sample exhibited a steady decrease in identification with religion or ethnicity from about $60 \%$ to $30 \%$. Lebanon seems to reflect a steady state where most of the population identify themselves as Lebanese as opposed to Muslim, Christian or Arab. All in all, self-identification with Islam and Arabism in the region decreased significantly over the past decade.

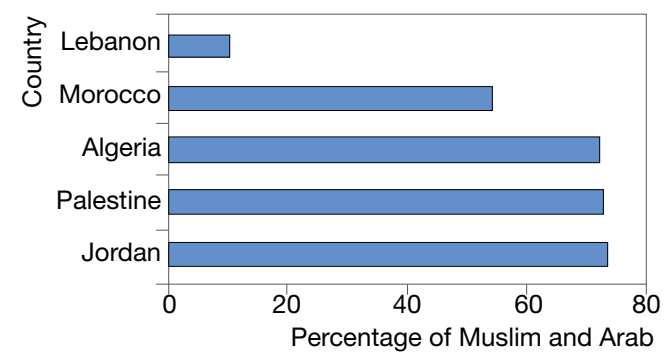

Figure 10. Percentage who self-identified with religion or ethnicity in 2006

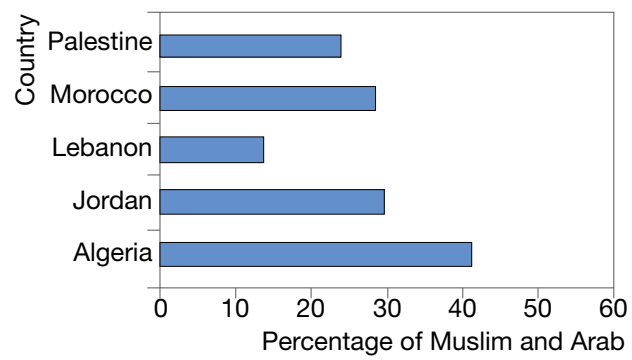

Figure 11. Percentage who self-identified with religion or ethnicity in 2016

\section{Trust}

Table 3 displays ordinary Arab citizens trust levels in their courts and police services in 2006 and 2016. Trust in the courts has dramatically decreased in all five countries. For instance, in Lebanon $45 \%$ of respondents in 2006 reported no trust at all or not very much trust in courts while $91 \%$ of the country's sample reported the same answers in 2016. Lebanon, Algeria and Palestine witnessed a significant decrease in trust in police services in those nations while Jordan and Morocco scored a moderate rise of trust in police services in the past decade. Judging from this exclusionary look at Arab citizens' trust levels in their political institutions, one can 
infer that, generally, Arab citizens have lower levels of trust in their institutions today compared to a decade ago.

Table 3

\begin{tabular}{c|rrrrr}
\multirow{2}{*}{ Percentages of No Trust at All and Not Very Much Trust in Courts and Pol } \\
\hline \multicolumn{4}{c}{ Country } & \multicolumn{4}{|c}{ Year } \\
\cline { 2 - 5 } & \multicolumn{2}{|c|}{2006} & \multicolumn{2}{c}{2016} \\
\hline & Courts, \% & Police, \% & Courts, \% & Police, \% \\
\hline Algeria & 56 & 46 & 68 & 51 \\
Lebanon & 45 & 38 & 91 & 51 \\
Jordan & 17 & 9 & 46 & 5 \\
Palestine & 38 & 40 & 64 & 53 \\
Morocco & 58 & 50 & 56 & 31 \\
\hline
\end{tabular}

\section{Tolerance}

Figure 12 displays Arab citizens' perceptions towards ordinary American citizens. Respondents were asked despite the negative consequences of American foreign policy in the region, do they believe that most Americans are good people. Results indicate that Arab citizens' image of American people improved significantly in the past decade. Large percentage increases in Jordan, Palestine, and Algeria have been observed since 2006, suggesting that more Arabs believe that most Americans are good people regardless of the country's active policy in the region. Lebanese citizens appear to have a stable view of Americans, a favorable outlook exhibited in the large percentage agreeing with the statement that "Americans are good people". Moroccans seem to have a favorable view towards Americans exhibited by the large percentage, over $60 \%$, which indicates their favorable attitude toward Americans.

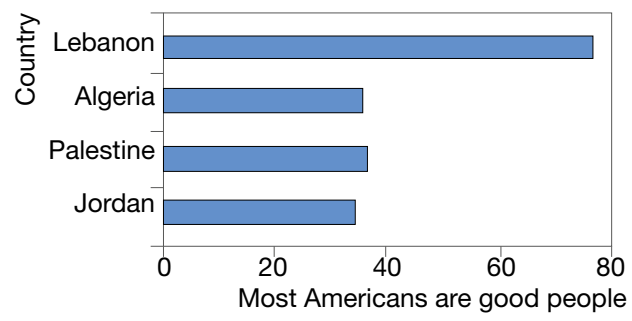

Figure 12. Arab citizens' perceptions towards ordinary American citizens, 2006

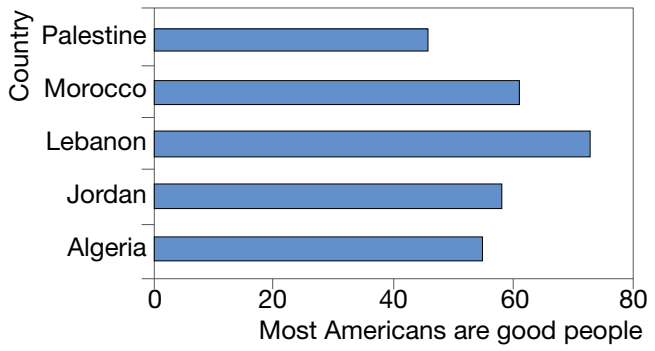

Figure 13. Arab citizens' perceptions towards ordinary American citizens, 2016 
On Palestine, Arab citizens today seem to be favorable towards a two-state solution for the ongoing conflict more so now than in the past. The Arab Barometer asked Arab citizens whether Arab states should accept Israel as a Jewish state in the Middle East in 2006, and opposition to the idea was high in all surveyed nations. Asked a similar question a decade later, Arabs seem to be less opposed to the establishment of Israel as a Jewish state in the heart of the Arab World. Arabs seem to be in favor of more friendly relations toward Israel than ever before in history. Notice how Egyptians, Moroccans, and Palestinians are almost divided on whether a two-state solution is an appropriate end to the conflict today whereas none of the Arab polities seemed divided on this question in 2006. Further, the number of people in each surveyed country who hold more favorable views towards brokering peace with Israel through the acceptance of the Jewish state or by installing two states, Israel being one of them, increased across the board.

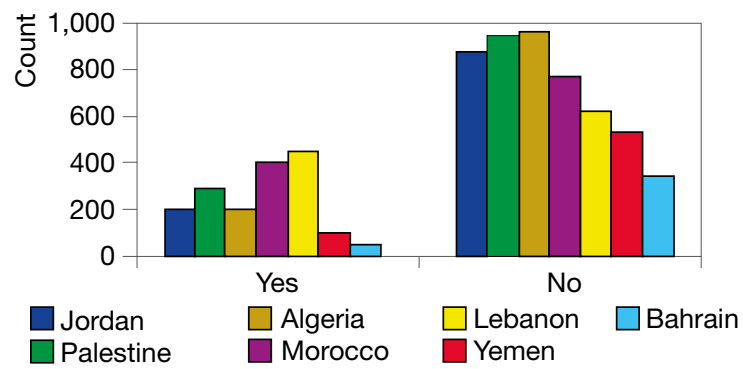

Figure 14. Should Arab countries accept Israel, 2006

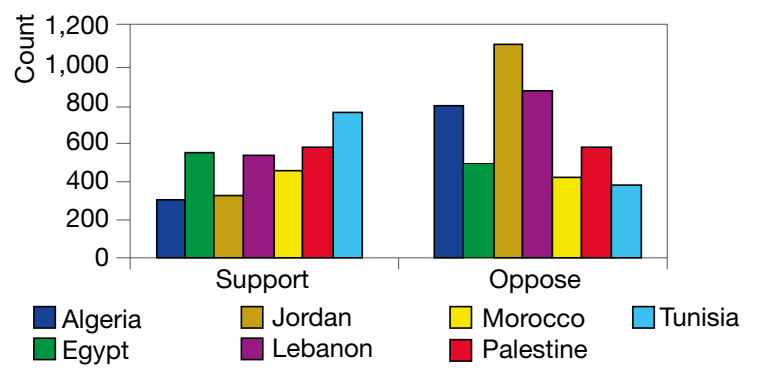

Figure 15. Should Arab countries accept Israel, 2016

\section{Discussion and Conclusions}

This research investigated whether social transformation processes such as modernization and globalization generate value shifts among ordinary citizens in the Arab world. Survey research evidence form the World Values Surveys and the Arab Barometer clearly indicate a discernable change in Arabs' political, social, and cultural perceptions from more conservative worldviews to more liberal preference schedules. Arabs today are more liberal than they have ever been.

While this research established the observational narrative of values change, using various indicators, the underlying mechanisms linking social transformation 
processes and values shift are still unclear. It has been argued here that the environment surrounding the current generations qualitatively differs from that existing during previous generations. Today the K-12 education system, working conditions, family relationships, and social interactions are not the same as those found in the Arab world during say the 1970s. Modernization and globalization have provided individuals with a higher selection of options, lifestyles, and choices at most levels and stages. Further, people have been exposed to idiosyncratic, eclectic, and peculiar styles, tastes, ways of doing things, and lifestyles in general thus making them more tolerant. People today are increasingly aware of ethnic, religious, and national differences more now than ever, creating an active sense of acceptance and toleration for many around the region.

Political scientists have conceptualized liberalism and conservatism, or Left versus Right, to refer to the struggle between challenging the status quo and openness to change (liberalism or Left) and supporting the status quo and resisting change (conservatism or Right). This means that challenging forces of power in society such as religion and traditional values and extending tolerance towards others (such as those who are foreign in cultural mores) represent attributes of liberalism. For the twentieth century, Islam, antagonism towards the West and Israel, and vehement pride in local traditions have defined societies in the Middle East and North Africa, making them indicators of conservative values since such forces have defined the political, cultural, and social arrangements of the region for centuries. The evidence purported by this study clearly establishes that Arabs are becoming less religious, more tolerant to foreigners (especially Western citizens), and are more prone to peace-making with Israel. Such shifts in attitudes lead one to conclude that Arabs are more liberal than they have ever been (Conover \& Feldman, 1981; Choma et al., 2012; Jahn, 2011).

One of the noteworthy shifts in the public opinion of Arabs is their increased tolerance toward gender equity (Kostenko, Kuzmuchev, \& Ponarin, 2016). While structural economic indicators of female participation in the workforce, female's attainment of higher education, and female political empowerment in the Arab World point to significant improvements, individual-level attitudes toward gender participation in social, political, and cultural avenues are supportive of the structural changes (Inglehart, 2017). Arabs are more likely to vote for a female candidate than they have ever been previously. They are also more likely to approve of a new female Chief Executive Officer for a public or private enterprise. Such changes clearly mark a departure from status quo traditions (where females belong in the household) to a more liberal understanding of the role women can play in society (where she can achieve the economic, social, and cultural benefits of socialization similar to men) (Metcalfe, 2008). This markedly underscores a shift in attitudes at the structural and individual levels, making the Arab World more liberal today.

This study carries many implications. First, it shatters current arguments supporting the suggestion that Arabs are more conservative than they have ever been before. Second, it opens new horizons for the systematic investigation of public opinion shifts in the region among researchers. Third, this research confirms earlier findings from different regions, thus supporting the claim that modernization leads to values changes among the mass public. 
To establish a more robust link between social transformation processes and values changes, archival data or retrospective research can help identify a multitude of attitudes in the Arab world during different epochs across the past century. This data can assist in detecting the differences in values in a fashion comparable to existing research on Western Europe and North America. Notice that this research is limited in its ability to recover comparable data on a larger set of items to establish robust comparisons between attitudes across the region.

Future research should utilize exploratory and confirmatory statistical techniques that could generate the dimensionality of values systems in the Arab world at different temporal periods. This exercise allows researchers to detect the overall direction and magnitude of shifts in a more precise manner compared to simply identifying the shifts using many survey items as this research has done. Dimensional analysis can inform researchers about the type and structuration of value systems and whether such patterns have changed over time.

\section{References}

Acemoglu, D., Hassan, T., \& Tahoun, A. (2017). The Power of the Street: Evidence from Egypt's Arab Spring. The Review of Financial Studies, 31(1), 1-42.

Arat, Z. (1988). Democracy and Economic Development: Modernization Theory Revisited. Comparative Politics, 21(1), 21-36.

Bartolini, S., \& Mair, P. (2001). Challenges to Contemporary Political Parties. In: L. Diamond \& R. Gunther (Eds.), Political parties and democracy (pp. 327-343). Baltimore, MD: Johns Hopkins University Press.

Bayat, A. (2011). A new Arab Street in Post-Islamist Times. Foreign Policy, 26. Retrieved from: http://foreignpolicy.com/2011/01/26/a-new-arab-street-in-postislamist-times/

Bayat, A. (2013). Life as Politics: How Ordinary People Change the Middle East. Palo Alto, CA: Stanford University Press.

Bolleyer, N., \& Storm, L. (2010). Problems of Party Assistance in Hybrid Regimes: the Case of Morocco. Democratization, 17(6), 1202-1224.

Bordoloi, S., \& Das, R. (2017). Modernization Theory. In: The International Encyclopedia of Geography. Willey-Blackwell and the Association of American Geographers.

Braizat, F. (2005). Post Amman Attacks: Jordanian Public Opinion and Terrorism. Amman: Public Polling Unit, Center for Strategic Studies.

Campante, F., \& Chor, D. (2012). Why was the Arab World Poised for Revolution? Schooling, Economic Opportunities, and the Arab Spring. The Journal of Economic Perspectives, 26(2), 167-187.

Ciftci, S. (2012). Secular-Islamist Cleavage, Values, and Support for Democracy and Shari'a in the Arab World. Political Research Quarterly, 66(4), 781-793. DOI: $10.1177 / 1065912912470759$. 
Dabashi, H. (2012). The Arab Spring: Delayed Defiance and the End of Postcolonialism: London: Zed Books Limited.

Gause III, F. (2011). Why Middle East Studies Missed the Arab Spring: The myth of Authoritarian Stability. Foreign Affairs, 81(90). Retrieved from: https:// www.foreignaffairs.com/articles/middle-east/2011-07-01/why-middle-east-studiesmissed-arab-spring

Hamarneh, M., Hollis, R., \& Shiqāqī, K. (1997). Jordanian-Palestinian Relations: where To? Four Scenarios for the Future. London: Chatham House.

Harik, I. (1987). Some Political and Cultural Considerations Bearing on Survey Research in the Arab World. In: M. Tessler et al. The Evaluation and Application of Survey Research in the Arab World. Boulder CO, Westview Press, 1987.

Hudson, M. (1995). The Political Culture Approach to Arab Democratization: the Case for Bringing it Back in, Carefully. Political Liberalization and Democratization in the Arab World, 1, 61-76.

Inglehart, R., \& Welzel, C. (2005). Modernization, Cultural Change, and Democracy: The Human Development Sequence. Cambridge, UK: Cambridge University Press.

Jackman, S. (1998). Pauline Hanson, the Mainstream, and Political Elites: the Place of Race in Australian Political Ideology. Australian Journal of Political Science, 33(2), 167-186.

Kitschelt, H. (1997). The Radical Right in Western Europe: A Comparative Analysis. Ann Arbor, MI: University of Michigan Press.

Langohr, V. (2002). An Exit from Arab Autocracy. Journal of Democracy, 13(3), 116-122.

Lerner, D. (1958). The Passing of Traditional Society: Modernizing the Middle East. New York, NY: Free Press.

Levitsky, S., and Way, L. (2002). The Rise of Competitive Authoritarianism. Journal of Democracy, 13(2), 51-65.

Lindberg, S. (2006). Democracy and Elections in Africa. Baltimore, MD: JHU Press.

Lipset, S., \& Rokkan, S. (Eds.). (1967). Party Systems and Voter Alignments. New York: Free Press.

Lynch, M. (2013). The Arab Uprising: the Unfinished Revolutions of the New Middle East. New York, NY: Public Affairs.

Malik, A., \& Awadallah, B. (2013). The Economics of the Arab Spring. World Development, 45(C), 296-313.

Marinov, N. (2012). Voter Attitudes when Democracy Promotion Turns Partisan: Evidence from a Survey-Experiment in Lebanon. Democratization, 20(7), 1297-1321. DOI: 10.1080/13510347.2012.690096.

Marsh, R. (2014). Modernization Theory, Then and Now. Comparative Sociology, 13(3), 261-283. 
Moreno, A. (1999). Political Cleavages: Issues, Parties, and the Consolidation of Democracy. Boulder, CO: Westview Press.

Nisbet, E., \& Myers, T. (2011). Anti-American Sentiment as a Media Effect? Arab Media, Political Identity, and Public Opinion in the Middle East. Communication Research, 38(5), 684-709.

Robbins, M., \& Tessler, M. (2012). The Effect of Elections on Public Opinion toward Democracy Evidence From Longitudinal Survey Research in Algeria. Comparative Political Studies, 45(10), 1255-1276.

Ryan, C., \& Schwedler, J. (2004). Return to Democratization or New Hybrid Regime? The 2003 Elections in Jordan. Middle East Policy, 11(2), 138-151.

Stoll, H. (2004). Social Cleavages, Political Institutions and Party Systems: Putting Preferences back into the Fundamental Equation of Politics. (Unpublished Doctoral Dissertation). University of California, Santa Barbara, Department of Political Science.

Telhami, S. (2006). Annual Arab Public Opinion Survey, February. College Park: University of Maryland, Anwar Sadat Chair for Peace and Development.

Tessler, M. (2003). Arab and Muslim Political Attitudes: Stereotypes and Evidence from Survey Research. International Studies Perspectives, 4(2), 175-181.

Tessler, M. (2011a). Public Opinion in the Middle East: Survey Research and the Political Orientations of Ordinary Citizens. Bloomington, IA: Indiana University Press.

Tessler, M. (2011b). Popular Views about Islam and Politics in the Arab World. International Institute Journal, 1(1). Retrieved from: http://hdl.handle.net/2027/ spo.11645653.0001.101.

Tessler, M., \& Jamal, A. (2006). Political Attitude Research in the Arab World: Emerging Opportunities. PS-Washington, 39(3), 433.

Tessler, M., Jamal, A., \& Robbins, M. (2012). New Findings on Arabs and Democracy. Journal of Democracy, 23(4), 89-103.

Tipps, D. (1973). Modernization Theory and the Comparative Study of National Societies: A Critical Perspective. Comparative Studies in Society and History, 15(2), 199-226.

Warwick, P. (2002). Toward a Common Dimensionality in West European Policy Spaces. Party Politics, 8(1), 101-122.

Weiner, M. (1966). Modernization: The Dynamics of Growth. New York: Basic Books.

Zogby, J., \& The Foundation for Arab Thought. (2002). What Arabs Think: Values, Beliefs and Concerns. Washington, DC: Zogby International.

\section{Acknowledgements}

I would like to thank Mr. C., the chief editor at Lighthouse Academic Services, LLC, for his meticulous editorial work. This research would have not been completed without such precious help from him. 